\title{
PRAWA CZLOWIEKA I PRAWA NARODÓW Z PERSPEKTYWY BIBLIJNEJ
}

Gdy ktoś czyta Powszechną Deklarację Praw Człowieka ONZ z 10 grudnia 1948 roku, od razu zauważa, że ma ona korzenie chrześcijańskie. Zrodziła się zresztą w ramach cywilizacji ukształtowanej przez chrześcijaństwo. Z kolei chrześcijaństwo ma swe korzenie w Objawieniu Bożym, spisanym w Biblii. Stąd też nasz temat, by pokazać to pierwotne źródło i podstawę praw człowieka i praw narodów, które z tych pierwszych wynikają.

Biblia wprawdzie nie mówi wprost o prawach człowieka czy prawach narodów. Jest ona przede wszystkim opisem historii Boga z człowiekiem i Boga z narodem wybranym czy później z innymi narodami. Owszem, Bóg w Biblii jest prawodawcą, ale nie w znaczeniu nadawania praw człowieka czy praw narodów w dzisiejszym rozumieniu. W Starym Testamencie - jak to policzyli rabini - Bóg daje człowiekowi 613 nakazów i zakazów, które po hebrajsku nazywane są Torą, co zostało potem przetłumaczone na język łaciński jako lex, lecz już w tym tłumaczeniu odbija się nie hebrajska, ale rzymska mentalność prawnicza. Tora bowiem nie oznacza „prawa”, ale „pouczenie”. Bóg, prowadząc historię człowieka, „poucza” go poprzez nakazy i zakazy, tak jak rodzic „poucza” swe dziecko, chroniąc je przez zagrożeniami i sprowadzając je na właściwą drogę. Wielokrotnie takie podejście znajdziemy na kartach Biblii. Bardzo często to sam Bóg nazywa siebie właśnie nauczycielem. W sposób szczególny widoczne jest to w Nowym Testamencie. Zwłaszcza Jezus określa sam siebie i jest określany słowami: „Nauczyciel”, „Mistrz”.

1 Por. J. Flis, Konkordancja biblijna do Pisma Świętego Starego i Nowego Testamentu Biblii Tysiąclecia, Warszawa 1996, s. 598, 688. 


\section{Prawa człowieka odkrywamy w Biblii nie przez definicje czy deklaracje}

W Biblii inicjatywa zawsze należy do Boga, to On wszystkiemu daje początek, On jest źródłem wszystkiego, a więc także źródłem praw człowieka. W jaki sposób? Otóż owe prawa odkrywamy w Biblii poprzez postępowanie Boga wobec człowieka.

Prawo człowieka do życia wynika z faktu, że Bóg jest jego stwórcą. To nie człowiek dał życie sam sobie i nie drugi człowiek dał mu życie... Zawsze tym dawcą i stworzycielem jest Bóg, zarówno w znaczeniu stworzenia pierwotnego, jak i stworzenia ludzi indywidualnych. Biblia przynosi szereg przykładów tego rodzaju ujęcia. Zarówno więc judaizm, jak i chrześcijaństwo podtrzymują to fundamentalne przekonanie o Bogu jako dawcy życia. Owszem, w historii pojawiały się różne inne interpretacje - jak choćby słynny w starożytności traducjanizm² ${ }^{2}$, ale Kościół zawsze opowiadał się za kreacjonizmem, stwierdzając, że rola rodziców polega tylko i aż na współpracy z Bogiem.

To Bóg jest dawcą i panem życia, nie człowiek. Taka jest też podstawa jednego z najważniejszych przykazań: Nie zabijaj.

\section{Szczególny status człowieka w świecie ${ }^{3}$}

Człowiek zostaje przez Boga w sposób szczególny wyróżniony i to już w momencie stworzenia. Sam jednak fakt, że człowiek jest stworzony przez Boga, nie wyróżnia go spośród reszty stworzenia, bo i ono stworzone jest przez Boga. Jest jednak kilka istotnych różnic pomiędzy stworzeniem reszty kosmosu a człowiekiem.

- Człowiek, według biblijnego opisu, został stworzony na samym końcu stworzenia, w szóstym dniu. Jeśli wziąć pod uwagę, że kolejne dni stworzenia wyznaczają zarazem hierarchiczne etapy kreacji, oznacza to, że człowiek stoi na najwyższym etapie aktu stwórczego.

- Terminem technicznym, którym posługuje się autor Księgi Rodzaju dla opisania stwórczego działania Bożego, jest czasownik „stwarzać” (bara). Biblia używa go zawsze w odniesieniu do Boga. Wyłącznie Bóg jest podmiotem tego czasownika. W pierwszym rozdziale Księgi Rodzaju siedmiokrotne użycie czasownika „stwarzać” (bara) odpowiada siedmiu dniom stworzenia. Jednakże czasownik ten nie jest rozdzielony równomiernie na siedem dni stworzenia. Przeciwnie, na pięć

2 Traducjanizm to teoria pochodzenia jednostek ludzkich od rodziców na zasadzie odgałęzienia duszy dziecka od dusz rodziców (łac. tradux - gałąź), stworzona przez stoików, a przejęta przez niektórych myślicieli chrześcijańskich, m.in. przez Tertuliana.

3 Por. M. Filipiak, Biblia o człowieku. Zarys antropologii biblijnej Starego Testamentu, Lublin 1979, s. 79-87; H. W. Wolff, Anthropologie des Alten Testaments, München 1990, s. 233-253. 
pierwszych dni stworzenia przypadają tylko cztery jego użycia, podczas gdy w dniu szóstym, w dniu stworzenia człowieka, jest on użyty aż trzykrotnie. Ani liczba siedem, ani liczba trzy naturalnie nie znalazły się tu przypadkiem. Podczas gdy siódemka oznacza pełnię, trójka wskazuje na wyróżnienie.

- Stworzenie człowieka jest poprzedzone specjalnym wezwaniem: „Uczyńmy człowieka na Nasz obraz, podobnego Nam” ( $\operatorname{Rdz} 1,26)^{4}$. Bóg mówi: uczyńmy (neaszeh), a stwarza (bara). Mamy więc znaczącą różnicę czasownika oraz formy. Bóg zapowiada zamierzenie w pierwszej osobie liczby mnogiej „my”: uczyńmy (pytanie: Bóg razem z kim?), a stwarza już w liczbie pojedynczej (narrator w tym wierszu aż trzy razy powtarza ten czasownik, jakby chciał, by czytelnik zwrócił uwagę na tę różnicę). Ta tajemniczość liczby mnogiej w tym wezwaniu da asumpt do różnorakich komentarzy. W przypadku chrześcijan będzie to najczęściej interpretacja trynitarna. Bóg wykonuje właściwą sobie część projektu stworzenia, dokończenie go pozostawia natomiast tajemniczemu drugiemu podmiotowi. Kto to jest? Bóg zamierzył człowieka na swój obraz i podobieństwo. Stworzył go natomiast jedynie na swój obraz. Jakby tylko połowa została zrealizowana. Ten brak zauważyli już niektórzy ojcowie Kościoła, zwłaszcza Klemensa Aleksandryjski, Orygenes i Bazyli z Cezarei. Ich komentarze będą szły w tym kierunku, że bycie na obraz Boży jest darem, podczas gdy podobieństwo do Boga czy raczej upodobnienie się do Niego jest zadaniem. Wynika to $\mathrm{z}$ faktu wolności człowieka, która, jak podkreślał także św. Jan Paweł II, jest nam dana, ale też i zadana5.

- Człowiek jest stworzony na obraz Boży. Jest to podkreślone dwukrotnie. Jest rzeczą uderzającą, że samo określenie „obraz” Boga występuje tu aż trzy razy. Owo bycie „na obraz Boży” będzie w późniejszych interpretacjach bardzo ciekawie i różnorodnie komentowane.

- W biblijnym opisie jest też podkreślone, że Bóg „stworzył ich mężczyzną i niewiastą", czego nie czyni się w przypadku stworzenia innych istot żywych, mimo że i w ich przypadku również występuje dymorfizm płciowy. Tekst biblijny podkreśla dymorfizm człowieka, który jest czymś znacznie więcej niż dwoistością płciową samca i samicy charakterystyczną dla zwierząt. Także w ludzkiej dwoistości mężczyzny i kobiety uwidacznia się owo bycie obrazem Boga.

Człowiek jest wprawdzie $z$ ziemi - adam, ale nie ogranicza się do niej. Bóg tchnął w niego swojego ducha życia. Istnienie człowieka zależy od tego właśnie tchnienia życia. Ono także wyróżnia go spośród całego stworzenia.

Na czym zatem polega owo „bycie na obraz i podobieństwo Boga”? Pytanie to będzie przez cały czas towarzyszyło antropologii chrześcijańskiej i różne nań bę-

${ }^{4}$ Cytaty biblijne za: Biblia Tysiaclecia, Poznań 2000.

${ }_{5}$ Por. Jan Pawel II, enc. Veritatis splendor, nr 86. 
dą padać odpowiedzi. Takie odpowiedzi zawarte są już jednak w samym tekście Księgi Rodzaju, a oto one:

\section{- Panowanie}

Już w momencie stworzenia dowiadujemy się, że człowiek ma panować „nad rybami morskimi, nad ptactwem powietrznym [...] i nad wszystkimi zwierzętami pełzającymi po ziemi” (Rdz 1, 28). Bardzo istotnym elementem owego bycia obrazem Boga jest panowanie nad wszelkim stworzeniem. Aby uniknąć jakichkolwiek nieporozumień, zwłaszcza z osobami o dużej wrażliwości ekologicznej, trzeba dodać, że w Biblii panowanie zawsze wiąże się nierozłącznie z troską i dbałością o to, nad czym się panuje.

- Bycie osobą i dialogiczność

Dla Biblii nonsensem jest mówienie o człowieku z pominięciem jego relacji z Bogiem. Człowiek stworzony przez Boga staje naprzeciw Niego: jak „Ty” wobec „Ty”. Bóg zwraca się do człowieka przez „Ty” i daje człowiekowi możliwość czynienia podobnie. W tej osobowej dialogiczności nie są wprawdzie równymi partnerami, niemniej jest to prawdziwa relacja osobowa i prawdziwy dialog. Dialog z Bogiem czyni z człowieka istotę, którą Bóg prowadzi poprzez historię. Człowiek i jego los nie są przypadkiem, kaprysem natury. Bóg jest opatrznością. Polega ona na tym, iż Bóg, panując, dba o człowieka, kieruje jego losem, a czyni to nawet wtedy, kiedy człowiek sam się od Niego odłącza.

Ta podstawowa relacja z Bogiem sprawia, że człowiek jest istotą relacyjną. Owa strukturalna relacyjność człowieka wyraża się nie tylko w jego odniesieniach do Boga, ale i w stosunkach z innymi ludźmi. Szczególną rolę w tej relacyjności odgrywa ludzka płciowość. Od samego początku człowiek jest mężczyzna i kobietą (isz i isza $)^{6}$. Biblia przyjmuje zasadniczą równość pomiędzy płciami. To właśnie odpadnięcie od Boga staje się przyczyną nierówności i niesprawiedliwych zależności. Owa relacyjność człowieka uwidaczniająca się na poziomie jego płciowości stanowi podstawę ludzkiej wspólnoty, która potem rozszerza się w rodzinę i naród. Relacje międzyludzkie dopóty są właściwymi relacjami, dopóki zachowana jest relacja człowieka z Bogiem.

Drugi rozdział Księgi Rodzaju dotyczy nie tylko tego, że człowiek potrzebuje drugiego, aby być szczęśliwym. To także bardzo mocne biblijne świadectwo o relacji i związku pomiędzy mężczyzną i kobietą. Relacja ta ma swoje oparcie jak zaznaczyliśmy - w byciu na obraz Boży. Bóg zsyła na adama-człowieka głębo-

6 Tekst hebrajski, nawet gdy mówi w sposób kolektywny o mężczyźnie i kobiecie, stosuje rzeczownik: adam (człowiek) - w liczbie pojedynczej. Talmud komentuje, że mężczyzna bez kobiety nie jest człowiekiem, gdyż jest napisane: „Stworzył ich jako mężczyznę i kobietę... i nazwał ich «człowiek». Tylko gdy mężczyzna jest zjednoczony ze swą żoną, może być nazwany człowiekiem" (Jewamot 63a). Por. S. Pecaric, Tora, Pardes Lauder, Księga pierwsza Bereszit, Kraków 2001, s. 36. 
ki sen, który tekst LXX określa mianem ekstasis ( $\mathrm{Rdz} 2,21)$. Jest to tłumaczenie, które sugeruje, iż nie był to zwyczajny sen, lecz sen szczególny, jakby człowiek nie był obecny sam w sobie, będąc znów w pełni w ręku Boga-Stwórcy.

\section{„Kość z moich kości i ciało z mego ciała...”}

Autor natchniony wcale nie dąży do tego, jak to swego czasu interpretowano, że kobieta jest niejako wtórnym stworzeniem wobec stworzenia właściwego, czyli mężczyzny, albo tylko pomocą. Wyrażenia biblijne podkreślają, że mężczyzna i kobieta są tej samej natury i tej samej godności. Pierwotnie jedyny człowiek zostaje niejako rozdzielony, z adama-człowieka zostaje niejako wydzielona kobieta, która staje się tą, która stoi naprzeciw, na wysokości oczu. To ktoś, kto stoi na tym samym poziomie, a nie na poziomie podporządkowanych zwierząt. Mężczyzna, mimo że nie był świadkiem stworzenia kobiety, od razu rozpoznał w niej kogoś równego sobie.

\section{Wzięta $z$ mężczyzny...}

Powszechnie uważa się, że tą częścią adama-człowieka, z którego została utworzona kobieta, jest żebro - cela. Tymczasem rabini odwołują się do innego znaczenia tego słowa, oznaczającego bok, stronę. W tym znaczeniu występuje to słowo w Księdze Wyjścia, gdzie oznacza „drugą stronę przybytku” (Wj 26, 20). Ponadto należy zwrócić uwagę, że słowo cela jest rodzaju żeńskiego. Stąd też interpretacja rabiniczna optuje za znaczeniem „strona” i tłumaczy odnośny fragment następująco: „Przebudował Bóg [tę] stronę, którą wziął z człowieka - w kobietę...”7. Mamy tu też do czynienia z grą słów: isz - isza, która wskazuje na tę samą naturę i godność obydwojga.

\section{„Dlatego opuści człowiek ojca i matkę...”}

Tu autor zmienia perspektywę. Do tej pory mówił o kobiecie w relacji do mężczyzny, teraz mówi o relacji mężczyzny do kobiety. To mężczyzna opuszcza ojca i matkę i idzie do swej żony. Pozostaje to w pewnej sprzeczności z ówczesnymi zwyczajami społecznymi, kiedy to żona szła do swego męża. Także ten kontrast

7 Por. S. Pecaric, Tora..., dz. cyt., s. 20. 
z ówczesnymi zwyczajami pokazuje, że chodzi o tę samą godność obydwojga w relacji „Ja” - „Ty”, zjednoczonych jednym ciałem i jednym sercem w „My”.

\section{Wolność}

Człowiek jest istotą wolna. Inaczej niemożliwe byłyby relacje osobowe z Bogiem. Wolność jest też tą cechą, która najbardziej upodabnia człowieka do Boga. Święty Bernard z Clairvaux powie o wielkości Boga: „Deus [...] omnes excedit an-

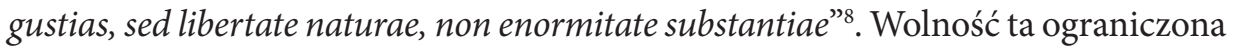
jest tylko przez jedno przykazanie: człowiek nie jest bez reszty panem siebie, nie on decyduje o tym, co jest dobrem, a co złem. Jest to logiczna konsekwencja statusu człowieka jako stworzenia. Człowiek bowiem nie jest Bogiem. Wolność człowieka nie jest sama dla siebie, służy relacyjności, jest dla miłości (człowiek bowiem realizuje się tylko w miłości), wolność jest więc po to, aby się dać, aby się poniekąd unicestwić w miłości. To wewnętrzny dramat wolności, który trwa od początku.

Wolność jednak może się także obrócić przeciwko człowiekowi. Zawarta w niej możliwość odrzucenia Boga i dialogicznej relacji z Nim staje się faktem. Owa pierwotna otwartość na relację miłości z Bogiem i dialog z Nim staje się wielką, otwartą, duchową raną - przepastną pustką, którą wypełnią wstyd i lęk. I tak wolność, która najbardziej upodabnia człowieka do Boga, otwiera też drogę do piekła. W sposób najbardziej dosłowny spełnia się w tym przypadku starożytna maksyma: Corruptio optimi - pessima.

\section{Wnioski}

Jak więc widzimy, już w pierwszych dwu rozdziałach Księgi Rodzaju mamy położone fundamenty pod podstawowe prawa człowieka:

- prawo do życia,

- prawo do ochrony niezbywalnej godności człowieka, wyrastającej z faktu, że człowiek jest uczyniony na obraz i podobieństwo Boże i nie może być traktowany jak zwierzę czy przedmiot. Co więcej, Bóg traktuje człowieka jako swego partnera w dialogu na poziomie „Ty - Ty”,

- prawo do równości między płciami i konsekwentnie do równości pomiędzy ludźmi,

8 „Bóg przekracza wszelkie ograniczenia, jednakże wolnością swej natury, nie wielkością swojej substancji”. Por. S. Bernardi Claraevallensis, De consideratione libri V, ad Eugenium III, Landshut 1845, s. 118, Libraria Josephi Thomanni (tłumaczenie własne). 
- prawo do wolności - Bóg nie zmusza człowieka do niczego - przeciwnie, stwarza mu pole do wolności i decyzji.

Wszystkie te prawa-dary Boga nie tyle ulegają zniszczeniu, ile stają się karykaturą samych siebie poprzez grzech.

Jak to widać w opisie skutków grzechu pierworodnego:

- człowiek staje się najpierw niewolnikiem lęku - traci swą wolność wewnętrzną, co potem przekłada się na zniewalanie innych,

- zostaje zniszczona równość pomiędzy mężczyzną i kobietą - „ku twemu mężowi będziesz kierowała swe pragnienia, on zaś będzie panował nad tobą",

- traci poczucie swojej godności i szacunek dla godności drugiego, co wyraża się we wstydzie i lęku przed drugim,

- wreszcie posuwa się do zabójstwa - bratobójstwa - Kain zabija Abla.

Bóg jednak od samego początku szanuje prawa, które sam nadał człowiekowi:

- także po grzechu szanuje jego godność, szuka go w raju, choć wie, gdzie on się ukrywa - nie odbiera mu wolności i nie czyni swym niewolnikiem,

- rozmawia nie tylko z mężczyzną, ale i z kobietą, traktując ich jako równych,

- szanuje nawet prawo do życia zabójcy Kaina - dając mu znamię i ochronę, żeby go nikt nie zabił.

Całe późniejsze objawienie Boga i historia zbawienia są odbudową w świadomości ludzkości konieczności poszanowania tychże fundamentalnych praw. Proces ten znajduje swój szczyt i pełnię w Objawieniu w Jezusie Chrystusie. Szczególny wyraz znajduje ten proces w Kazaniu na Górze (por. Mt 5, 1 - 7, 28), w którym Jezus przedstawia siebie jako tego, który doprowadza prawo do Pełni. To magna charta praw człowieka, ufundowanych na dobroci i miłości Boga, sięgającej aż miłości nieprzyjaciół, a więc poszanowania podstawowych praw osoby ludzkiej także w odniesieniu do wroga.

\section{Prawa narodu}

Tak jak Bóg stwarza człowieka, tak też tworzy sobie lud - naród wybrany. Owo powstanie ludu - narodu wybranego zawarte jest już w zalążku w fakcie relacyjności człowieka, wyrażonej najpierw w jego płciowości, potem w rodzinie, a następnie w rodzinie rozszerzonej, czyli w narodzie. Taką zresztą genezę narodu ukazuje Biblia. Historia Izraela rozpoczyna się od Abrahama, Izaaka i Jakuba - tzw. patriarchów - którzy są protoplastami całego narodu. I tak jak Abraham doświadczył wybrania przez Boga, tak doświadcza go też Izrael - stając się narodem wybranym. To wybranie jest jednoznaczne z wyzwoleniem Izraela $\mathrm{z}$ niewoli egipskiej. Możemy tu zatem mówić już o pierwszym prawie narodu, jakie Bóg nadaje Izra- 
elowi, i jest to prawo do życia w wolności. Z niewolników, i to zagrożonych eksterminacją, Izraelici stają się narodem wolnym, do tego narodem ludzi wolnych.

Jak podkreśla Biblia, Bóg wybrał Izraela (por. Pwt 7, 7; Iz 41, 8) i powołał go (por. Iz 48, 12) nie ze względu na jego wielką liczebność, siłę lub zasługi (por. Pwt 7, 7; 8, 17; 9, 4), lecz z miłości (por. Pwt 7, 8; Oz 11, 1). Bóg kocha swój naród i zarazem uczy tej miłości Izraelitów. Bardzo żywa świadomość całkowitej zależności od Boga towarzyszy izraelskiemu odczuciu niezawisłości narodowej”.

Potem przychodzi Przymierze na Górze Synaj i ten akt ukonstytuowania narodu oznacza, że od tej pory wszystko w dziejach Izraela będzie się rozgrywać na dwu płaszczyznach: na płaszczyźnie historii i na płaszczyźnie wiary. Święte przymierze opieczętowane krwią ofiary zostało zawarte, a jedną z jego stron jest dwanaście pokoleń izraelskich (por. Wj 24, 8). Na mocy tego przymierza Jahwe staje się Bogiem Izraela, a Izrael ludem Jahwe (por. Pwt 29, 12; Kpł 26, 12; Jer 7, 23; Ez 11, 20). To ukonstytuowanie się Izraela nie jest w żadnym stopniu przez Boga narzucone. Izrael demokratycznie wybiera prawo nadane przez Boga. Mojżesz stawia cały lud przed wyborem, czy chce tego prawa, czy nie... I cały naród przyjmuje je jako swoje - $\mathrm{w}$ wolności ${ }^{10}$.

Niezwykle ważny element tożsamości Izraela jako narodu stanowi tradycja narodowa, która jest zarazem tradycją religijną, w której przekaz wartości narodowych łączy się ściśle z przekazem wiary, zwłaszcza w ramach świąt - szczególnie święta Paschy. Można by tu mówić o prawie do własnej tożsamości i zachowania tradycji narodowych. Wyraża się ono w centralnej modlitwie Izraela, którą kilka razy w ciągu dnia powtarza każdy wierzący Izraelita aż po dzień dzisiejszy: Shema Israel...

Izrael jako naród ma do wypełnienia w historii pewną misję. Nie jest narodem zamkniętym w sobie, przekonanym o swojej wyższości nad innymi narodami. Bóg, owszem, wybrał go spośród innych narodów, lecz nie dlatego, że jest od nich lepszy czy większy... Mojżesz mówi do ludu zgromadzonego pod Górą Synaj: „Pan wybrał was i znalazł upodobanie w was nie dlatego, że liczebnie przewyższacie wszystkie narody, gdyż ze wszystkich narodów jesteście najmniejszym, lecz ponieważ Pan was umiłował i chce dochować przysięgi danej waszym przodkom" (Pwt 7, 7-8a).

Misją, którą Izrael ma do spełnienia w stosunku do innych narodów, jest bycie dla nich świadkiem Boga jedynego (por. Iz 44, 8); ludem-pośrednikiem, poprzez który zostaną zadzierzgnięte więzy pomiędzy Bogiem a całą ludzkością, tak że w rezultacie z całej ziemi popłynie chwała do Boga (por. Iz 45, 14n. 23n)

9 Por. X. Leon-Dufour, Słownik teologii biblijnej, Poznań 1973, s. 426.

10 Por. X. Leon-Dufour, Stownik teologii biblijnej, dz. cyt., s. 426. 
i wszystkie narody będą uczestniczyły w błogosławieństwie Bożym (por. Rdz 12, 3; Jer 4, 2; Syr 44, 21).

A zatem to wybranie Izraela skierowane jest do wszystkich narodów. To, co odnosi się do Izraela, przewidziane jest też dla wszystkich innych narodów. Może się ono jednak realizować tylko wtedy, jeśli te narody otworzą się na objawienie Boga dokonane najpierw w Izraelu, a potem przez doświadczenie wiary w nich samych.

To otwarcie na inne narody jest w Starym Testamencie zapowiadane, ale jego realizacja ma charakter bardzo ograniczony. Co gorsza, dzieje się nawet coś przeciwnego. Bóg wyrzuca Izraelowi poprzez proroków, że nie tylko nie pełni powierzonej mu wobec innych narodów misji, ale wręcz czyni coś odwrotnego - bezcześci Jego imię na oczach innych narodów. Dlatego też Bóg mówi:

Nie z waszego powodu to czynię, domu Izraela, ale dla świętego imienia mojego, które bezcześciliście wśród ludów pogańskich, do których przyszliście. Chcę uświęcić wielkie imię moje, które zbezczeszczone jest pośród ludów, zbezczeszczone przez was pośród nich, i poznają ludy, że Ja jestem Pan - wyrocznia Pana Boga - gdy okażę się Świętym względem was przed ich oczami. Zabiorę was spośród ludów, zbiorę was ze wszystkich krajów i przyprowadzę was z powrotem do waszego kraju, pokropię was czystą wodą, abyście się stali czystymi, i oczyszczę was od wszelkiej zmazy i od wszystkich waszych bożków. I dam wam serce nowe i ducha nowego tchnę do waszego wnętrza, odbiorę wam serce kamienne, a dam wam serce z ciała. Ducha mojego chcę tchnąć w was i sprawić, byście żyli według mych nakazów i przestrzegali przykazań, i według nich postępowali. Wtedy będziecie mieszkać w kraju, który dałem waszym przodkom, i będziecie moim ludem, a Ja będę waszym Bogiem (Ez 36, 22-28).

To prawdziwie wielkie otwarcie na inne narody dokonuje się dopiero w Nowym Testamencie. Wszystkie cztery Ewangelie kończą się rozesłaniem uczniów przez Jezusa do wszystkich narodów. Przy czym trzeba zaznaczyć, że wszyscy ci uczniowie są Izraelitami i niosą do tych narodów nie tylko przesłanie Nowego Testamentu, ale także całe dziedzictwo Izraela, wraz z prawami, które Bóg nadał narodowi wybranemu.

Ten problem uczestnictwa w dziedzictwie Izraela od strony teologicznej opracował z niezwykłą przenikliwością i głębią św. Paweł - nazwany Apostołem Narodów. Zawarte jest ono w jednym $z$ najważniejszych jego listów, skierowanym do wspólnoty chrześcijan w samym sercu Cesarstwa Rzymskiego, czyli w Rzymie. Święty Paweł poświęca tej sprawie aż trzy rozdziały tego listu (por. Rz 9-11).

Apostoł przedstawia dzieło wprowadzenia w dziedzictwo Izraela nie jako likwidację dotychczasowej tożsamości narodowej, ale jako wszczepienie w szlachetną oliwkę Izraela, a więc uszlachetnienie własnego dziedzictwa przez nowe soki. 
Jeśli spojrzeć na późniejsze dzieje chrześcijaństwa, widać wyraźnie, w jaki sposób Kościół realizował tę ideę. Dokonywało się to zawsze poprzez tzw. inkulturację, czyli wypełnienie chrześcijańską limfą kultury danego narodu. Przykłady można by mnożyć, zarówno ze starożytności, jak i średniowiecza, kiedy to Polska przyjęła chrześcijaństwo i została wszczepiona w szlachetną oliwkę Izraela, jak też i z czasów nowożytnych czy współczesnych.

\section{Wnioski}

Niech za wnioski końcowe odnośnie do praw narodu posłużą słowa św. Jana Pawła II z pamiętnej homilii na placu Zwycięstwa w czasie jego pierwszej pielgrzymki do ojczyzny, które mówią właśnie o tym fakcie i jego roli w historii naszego narodu:

Kościół przyniósł Polsce Chrystusa - to znaczy klucz do rozumienia tej wielkiej i podstawowej rzeczywistości, jaką jest człowiek. Człowieka bowiem nie można do końca zrozumieć bez Chrystusa. A raczej: człowiek nie może siebie sam do końca zrozumieć bez Chrystusa. Nie może zrozumieć ani kim jest, ani jaka jest jego właściwa godność, ani jakie jest jego powołanie i ostateczne przeznaczenie. Nie może tego wszystkiego zrozumieć bez Chrystusa...

Jeśli jest rzeczą słuszną, aby dzieje narodu rozumieć poprzez każdego człowieka w tym narodzie - to równocześnie nie sposób zrozumieć człowieka inaczej jak w tej wspólnocie, którą jest jego naród. Wiadomo, że nie jest to wspólnota jedyna. Jest to jednakże wspólnota szczególna, najbliżej chyba związana z rodziną, najważniejsza dla dziejów duchowych człowieka. Otóż nie sposób zrozumieć dziejów narodu polskiego - tej wielkiej tysiącletniej wspólnoty, która tak głęboko stanowi o mnie, o każdym z nas - bez Chrystusa. Jeślibyśmy odrzucili ten klucz dla zrozumienia naszego narodu, narazilibyśmy się na zasadnicze nieporozumienie. Nie rozumielibyśmy samych siebie ${ }^{11}$.

11 Św. Jan Paweł II, Homilia w czasie Mszyśw. odprawionej na placu Zwycięstwa (2.06.1979), http://nauczaniejp2.pl/dokumenty/wyswietl/id/538/pos/13/haslo/Wyszy\%C5\%84ski\%20 Stefan,\%20kardyna\%C5\%82,\%20Prymas\%20Tysi\%C4\%85clecia (27.03.2018). 


\section{Abstract}

\section{Human rights and the rights of the nation from the Biblical perspective}

Nowhere in the Bible are human rights or the rights of the nation explicitly discussed. In the Scripture God is the ultimate giver of the law and $\mathrm{He}$ gives and constitutes it not only by His spoken word, but also by His own attitude to man and to various nations and by His relation to them. Already the first chapters of the Book of Genesis show the foundation of the most important human rights such as the right to life, to freedom, to personal inalienable dignity, to the equality between men and women and among all human beings.

Similarly, it is possible to recognize the rights of the nations. God chooses a nation (Israel), frees it from the slavery in Egypt, protects and leads it in the desert, gives it laws and finally gives it the Promised Land. But these gifts are not only for the people of Israel, for it is their and later also our - all Christians' mission to show the holiness and the salvation of God to other nations. God's will is to make all nations participants of the same gifts and rights. 